\title{
Testing the Causal Nexus between Output and Unemployment: Swedish Data
}

\author{
A. Khalik Salman \\ Correspondence: Department of Social Sciences, Mid Sweden University, SE- 83125 Östersund, Sweden. Tel: \\ 46-0-63-165-794. E-mail: khalik.salman@miun.se
}

Received: June 12, 2012

Accepted: July 13, 2012

Online Published: September 3, 2012

doi:10.5539/ibr.v5n10p29

URL: http://dx.doi.org/10.5539/ibr.v5n10p29

\begin{abstract}
In this paper we aim at testing for the Granger causality test between real GDP and unemployment in Sweden. We model a VAR (4) model on Swedish two macro-economic variables, namely, the gross domestic product (GDP) and unemployment (Un) for the period 1993:Q1 - 2011:Q2. Our main aim is to supporting further empirical evidence so as to identify the relationship between the GDP and unemployment in terms of females, males and total unemployment, with special reference to Sweden. A Granger causality test is used. The test shows that it is the GDP Granger that causes unemployment but not the other way around. An econometric model is deployed and developed on the basis of Okun's Law. Total unemployment, male unemployment and female unemployment coefficients of the relationship between the GDP and unemployment coefficients are diverted from Okun's coefficient and they are found to be approximately 8 per cent and statistically significant for Sweden. This stayed almost steady over time. This result also has important implications for determining macroeconomic policy.
\end{abstract}

Keywords: causality test between GDP and unemployment, Okun's Law, VAR model

\section{Introduction}

In econometrics, the variables included in the Vector Autoregressive (VAR) methodology have to be stationary before testing for causality in the Granger approach. Non-stationary variables used to be differenced (to make them stationary) before applying the causality test on the VAR modelling. An exception from this role can be achieved when the variables are non-stationary, integrated of the same order and cointegrated. In the case we can run the causality test on the cointegrated VAR model without the need of taking the differences of these variables. In this paper we apply the Johansens' (1988) tests for cointegration. Given the selected VAR models have shown to be cointegrated, have then focused on Granger causality in this research.

In this study we consider the Swedish economy during the period 1993:Q1 - 2011:Q2. The period of study covers a time of a major regulation and change in Swedish labour market policies, when the current financial crisis in industrialized countries and in Sweden led to a decline in GDP growth and an increase in the unemployment rate. Our evaluation is also an attempt to highlight the effects of a slowdown in growth on unemployment. The related empirical studies originally found that Okun's relationship between slow economic activity and the unemployment rate has various implications and is statistically significant during the business cycle.

Compared to the international labour market, the Swedish labour market was performing very well throughout the 1970s and 1980s. In the early 1960s, the female employment rate rose significantly, from $54 \%$ in 1965 to $82 \%$ in 1989 and $62.9 \%$ in 2011; total employment increased alongside with this particular increase in female participation Holmlund (2003). The economic downturns of the early 1990s, particularly in manufacturing, construction and the retail sectors, affected employment, which decreased from $83 \%$ to $73 \%$ between 1990 and 1993. Another change began in 1997 with a rise in GDP growth and employment. The employment rate was $75 \%$ in 2001, but since then dropped steadily each year to 73\% in 2005 and to 65\% in 2011, SCB (2006, 2011).

Typically, economic downturns correlate to an increase in unemployment. This negative relationship has been called "Okun's Law". Okun (1962) is known for its simplicity since it includes two domestic macro-economic variables. Furthermore, the relationship seems to have much empirical investigations. In reality, although Okun's Law is considered a statistical form of interrelation among two macro-economic variables, it may be subject to revision in an ever-evolving macro-economics. Thus questions remain: Is Okun's coefficient is dependable and 
steady relation? Is the Okun's finding helps to forecast future values of unemployment? We will also try to answer the following questions: Are there differences between the genders, or is there a policy of discrimination in the Swedish labour market? If there are no differences or they have equal opportunities, then the coefficients of estimations for the male and female unemployment rate can be the same. The calculation has been made using the Granger causality test between output and unemployment in Sweden; however, there have been many methods of formulating equations for Okun's hypothesis given in the literature. In almost all cases the variables involved in the model were traditionally included in a differentiated form. It is also well known that differentiating between macroeconomic variables damages the long term information in the variables. In order to avoid such a situation, we work with the variables at their own level. This means that if the variables are non-stationary and have a stochastic process, they must be first integrated with the same order and then cointegrated before processing in further analysis. In this paper we found our variables to be non-stationary and integrated of the first order. Based on these findings, we later focus on testing for causality between GDP and unemployment in Sweden. Given our data series of the Gross Domestic Product (GDP) and Unemployment (Un) from 1993:Q1 to 2011:Q2, we specify a VAR methodology with four lag lengths i.e., VAR (4) framework. By processing in this manner we test for the causality between these variables and at the same time keep the longrun relationship equilibrium between them.

In order to improve the validity of results, this study implements a different method, analysing more variables than previous studies. In addition, we adjust the research perspective, and use more variables for the labour market and thereby extend previous research. Whereas variables such as female and male unemployment have not been regarded as the important determinants in a relationship between the business cycle and employment function in existing quantitative studies of labour market in Scandinavian, they are highlighted in our study. Furthermore, former Scandinavian studies have not considered the Granger test to measure the long-run equilibrium relationship between real GDP and unemployment (female and male unemployment). Most of the previous international studies measured the relationship by total unemployment only. This study contributes to the literature on the macro-econometrics of the economics of the labour market by applying the Granger test method so as to examine the impact of GDP on unemployment rate, for the first time.

\section{Previous Related Studies}

Various former studies have estimated the relationship between unemployment and growth. Okun (1962) presented two empirical relationships for the rate of unemployment to output, which have become related with his study. These empirical relationships have been adopted as rule since then. However, both have been extended by later economists to include elements that Okun had omitted in his analysis.

Real GDP and employment usually move together. Okun documented that the US unemployment rate tended to fall by $1 \%$ point for every $3 \%$ point rise in real GDP. A large body of empirical studies noted that GDP fluctuations have considerable consequences on unemployment rates. These consequences are expected to be different in industrialized countries and in the USA. The Okun coefficient will be larger in industrialized countries and smaller in the USA, Canada and the United Kingdom Lee (2000). This result should be expected, because these countries have a much less regulated labour market and frequently lay workers off during economic downturns, while most other developed countries have stronger restrictions on laying off employees (Note 1).

Several studies after Okun have shown that aggregate economic activity does affect employment rate. Lee's (2000) empirical study found that the real effects of economic growth on employment are that the coefficients are considerably different across countries, possibly due to the rigid circumstances of the labour markets. Prachowny's (1993) empirical study provides additional evidence of the negative relationship between economic growth and unemployment in the U.S: this finding is considered further support for the view that Okun's law is help to forecast future value of unemployment.

In addition, Cuaresma's (2003) study also considers the reality of Okun's parameter with a higher value for contraction than for the recovery phase. Padalino and Vivarelli (1997) and Dökpe (2001), found a strong relationship between aggregate economic activity and employment for most of the main industrialized countries (G-7). Moosa (1997) used data for the US, Canada, Europe and Japan to assess the relationship between aggregate economic activity and employment by means of a (SUR ) seemingly unrelated regressions. This study stressed that the responsiveness of employment to economic activity seemed to be greater in the U.S and Canada than in other industrialized countries and Japan by SUR technique proposed by Zellner (1962)'s Iterative (Note 2). Conversely, Piacentini and Pini's (1998) model fails to identify any real positive effect of aggregate economic activity on employment, Under this circumstance, real GDP might bear no relationship whatsoever to 
employment, thus unemployment might actually occur even with economic growth. Pianta et al. (1996) found evidence in the cases of 36 manufacturing sectors amongst the G-7 countries that employment does have to move positively together with economic growth, but have not show to have a significant effect on employment.

As the relationship between real GDP and unemployment is determined by factors such as technological change, laws, labour market politics and transitions, demand, welfare benefits, population change, global competition and privatization, it is believed that the Okun coefficient changes over time. Some economists showed that GDP fluctuations have considerable consequences on the unemployment rate. These consequences are expected to be different in industrialized countries and in the US Lee (2000). As it turns out, however, it now appears that Okun's Law might actually be quite a helpful instrument in making comparisons across countries and over time.

The main aim of this study is to supporting additional empirical study to measure the relationship between the GDP and unemployment. This relationship has been discussed in the empirical literature. There is a large number of literature on this topic have noted that such a relation appears to have weakened in early years, both in Sweden and in other industrialized countries. This study is important for Sweden and other industrialized countries for several reasons: firstly, Sweden provides an interesting context for this study due to their situation as domestic macro-economic in transitions, which had equalled the position of the more industrial European countries in the period under investigation. Secondly, it had followed new policies for openness and the labour market, and created more dependence on advance in information technology, moving towards increased internationalization of all economic activity, and profitability between national and international markets. Thus, an innovation of this study is consideration of the evolution of the relationship between the business cycle and unemployment during a country's transition to a new technological status. Additionally, the period of study covers three major recession phases in Sweden and the other industrialized countries, which contributed to slowing down aggregate economic growth. Thirdly, a large amount of literature on this topics focus on the US economy and G-7 countries, and to our knowledge, the Granger causality relation of real GDP and unemployment has not been examined for Sweden considering a variety of econometric specifications. We also apply the Johansen (1988) procedure for cointegration, which has not been used in any of the above mentioned studies; in spite of its general popularity. The paper contributes to the literature of macro-econometrics by studying the causality nexus between the business cycle and unemployment.

Most previous studies have used the ordinary last squared method (OLS), rolling OLS, seemingly unrelated regressions (SUR) and asymmetry dynamic model techniques to analyse the relationship between output and unemployment. In this paper we conduct the Granger causality test with the Johansen cointegration method.

We utilise this procedure since it treats the included variables endogenously and because it is robust to the normalisation factor. Moreover, it allows inclusion the variables in their own levels and hence keeping the long run relationship between them instead of what was traditionally done in the previous research (i.e., by taking the differences of the variables in order to make them stationary).

\section{Data, Model Specification and Methodology}

The causal relationship between real GDP and unemployment (Un) is investigated by using the quarterly data for two macroeconomic variables (real GDP and unemployment). The data as collected from the Organisation for Economic Co-operation and Development (OECD) database for the period of study 1993:Q1 to 2011:Q2. The output variable is real GDP measured in price, 2010. The calculations were performed using the statistical program package STATA Version 11.0.

Granger causality test, due to Granger (1969), implies that one variable precedes the other variable. In our study, when we test if GDP Granger causes Un is to see how much of the current values of Un is explained by past values of GDP, and vice versa. Note that the causality might have two directions simultaneously. This can be done by estimating the following VAR model and then apply the test:

$$
\begin{gathered}
U n_{t}=a_{0}+\sum_{i=1}^{k} a_{i} U n_{t-i}+\sum_{i=1}^{k} b_{i} G D P_{t-i}+e_{1 t} \\
G D P_{t}=c_{0}+\sum_{i=1}^{k} c_{i} U n_{t-i}+\sum_{i=1}^{k} f_{i} G D P_{t-i}+e_{2 t}
\end{gathered}
$$

where $e_{1 t}$ and $e_{2 t}$ are assumed to be stochastic white noise error terms with means equal to zero and constant variances.

Note that the lag order of the VAR model will be selected according to the Schwarz (1978) information criteria (SIC). If all the values of $b_{i}$ are simultaneously equal to zero, we can conclude that GDP does not cause Un. In 
the same manner, if all the values of $c_{i}$ are simultaneously equal to zero, we can conclude that Un does not cause GDP.

Since these variables are usually non-stationary and have stochastic trends, before testing for Granger causality we have to check whether these variables are cointegrated (i.e., whether a long run relationship does exist among them). Note that before conducting the cointegration test, we apply the augmented Dickey-Fuller (1979 and 1981) ADF test in order to insure that the variables are non stationary and integrated of the same order. Results of these tests are summarized in (Tables A1, A2, A3 and A4). The results of the cointegration test are reported in Tables (B1, B2 and B3).

Then the Johansen (1988) maximum likelihood estimator has been applied. The number of lags, $k$, has been defined as equal to 4 Using the SIC criteria the VAR (4) model is selected. This model has also shown to be well specified when applying a number of diagnostic tests. Results of these tests are summarized in tables (c1, c2 and c3). We then used the F-test for testing for Granger causality between the variables in the VAR (4) model. Our purpose is to investigate the causal relation between the GDP and Unemployment.

Numerous statistical diagnostic tests are carried out in our model selection procedure: Breusch (1978) and Godfrey (1978) commonly used autocorrelation test; White's (1980) test for heteroscedasticity was applied; Engle's (1981) LM test for autoregressive conditional heteroscedasticity ARCH; Ramsey's (1969) RESET test for omitted variables and functional misspecification. It is also of interest to use Jarque and Bera's (1987) test for non-normality. The cumulative sum of squares (CUSUMSQ) test for parameter stability Brown, Durbin, and Evans (1975) can be applied. The relevant results for tests are given in Tables' c1, c2 and c3. The main advantage of using such procedures, however, is that one can avoid less than adequate models, which could lead to extremely misleading results and inferences. The statistical results and diagnostic tests show that the coefficients estimated are corrected and all the diagnostic tests are accepted and significant. Results of these statistical and diagnostic tests are summarized in Tables (c1, c2 and c3).

\section{Estimation Procedures for Significance and Granger Causality}

In this paper we intend to study the causal relationship between the Swedish GDP and unemployment by performing a vector autoregressive (VAR) methodology that allows for causality testing in the Granger technique. Different tests are carried out for each method of study. First, we apply the ADF test in order to insure that the variables are non stationary and integrated of the same order. Accordingly, tests for cointegration have to be existed. Secondly, we determine the suitable lag lengths degree of the VAR framework by considering a number of VAR models using Schwarz (1978) model selection criteria. Thirdly, if the chosen model is shown to be tolerable, using a battery of diagnostic checking, we then test for cointegration between the variables in the VAR model using the Johansen's technique Salman and Shukur (2004). When we find enough evidence for cointegration, the next step is to test for Granger causality approach and make inferential statements.

\section{Empirical Results}

This section presents the results of applying the Granger causality test on the VAR (4) model in (1) and (2). The test has been applied on data for total (males and females) together, males only and females only. The results for the test can be found in Tables 1 and 3, respectively. In all cases, the test results indicate that during the period of study 1993:1 - 2011:2, there is a one directional causality effect from GDP to unemployment. We could not find any evidence or effects in the opposite direction. Looking at the p-values in the table, we can conclude that GDP significantly Granger -causes unemployment.

The strength of the causality from GDP to the total unemployment (TUn) is highly significant, while causality from TUn to GDP have appeared to be statistically non-significant (see Table 1). This might indicate that the nature of causality between these two variables is uni-directional and going from GDP to TUn but not the other way around. This might mean that any variation in past GDP can affect the unemployment negatively or render it unstable.

When using the same method to test for causality from GDP to the data for males and females unemployment, we obtained the results that GDP Granger causes unemployment, as summarized in Tables 2 and 3.

Table 1. Testing for causality in the Granger approach for Sweden using total data and applying VAR (4)

\begin{tabular}{lc}
\hline Null Hypothesis & P-value \\
\hline TUn does not Granger Cause GDP & 0.090 \\
GDP does not Granger Cause Un & 0.001 \\
\hline
\end{tabular}


Table 2. Testing for causality in the Granger approach for Sweden using male data and applying VAR(4)

\begin{tabular}{lc}
\hline Null Hypothesis & P-value \\
\hline MUn does not Granger Cause GDP & 0.081 \\
GDP does not Granger Cause Un & 0.007 \\
\hline
\end{tabular}

Note: This table is derived from Table A2.

Table 3. Testing for causality in the Granger approach for Sweden using female data and applying VAR (4)

\begin{tabular}{lc}
\hline Null Hypothesis & P-value \\
\hline FUn does not Granger Cause GDP & 0.083 \\
GDP does not Granger Cause Un & 0.001 \\
\hline
\end{tabular}

Note: This table is derived from Table A3.

Sweden has experienced an unemployment recovery in the sense that unemployment has increased, even though GDP has reversed its negative path. The results presented in this study suggest a temporary lag, rather than a fundamental change in the relationship between GDP and unemployment. The regression results show that Sweden has total unemployment, male, and female unemployment coefficients with respect to the first lag of the GDP that are approximately $-0.8 \%$ during the period of study 1993:1-2011:2. Results for these coefficients are summarized in Table 4.

Table 4. Estimates of coefficients for the relationship between GDP and unemployment*

\begin{tabular}{lllll}
\hline Unemployment items & Coefficients & SE & T-Statistic & P-value \\
\hline Total unemployment (t-1) & -0.076 & 0.017 & -4.434 & 0.0000 \\
Males unemployment & -0.084 & 0022 & -3.799 & 0.0003 \\
Females unemployment & -0.079 & 0.018 & -4.478 & 0.0000 \\
\hline
\end{tabular}

Note: * This table is derived from Tables B1 - B3.

This indicates a fairly strong negative and statistically significant relationship between GDP and all the items of unemployment. From the multivariable regression, it was concluded that the recent situation in the Swedish economy could be explained by lagged GDP, but only the first lag has shown to have a statistically significant effect on all Swedish unemployment items. It is also been shown that the unemployment coefficients with lagged two GDP, through lagged four GDP, have positive and not statistically significant effects on the Swedish unemployment items. However, these lags periods are existed in the model for the sake of specification since the model selection criterion and the diagnostic tests indicated the appropriateness of this number of lags.

\section{Summary and Remarks}

This section analyses the empirical results for the causal nexus between GDP and unemployment in Sweden from the 1993: Q1 to the 2011: Q2. The results show that only GDP Granger causes unemployment (total unemployment, male unemployment and female unemployment). It should be noticed that in all estimations the variables have been appeared to be both integrate of the first order I (1), and cointegrated. The VAR (4) model is recommended following model selection criterion and a battery of diagnostic tests, and was thus chosen for this study.

Based on the Swedish data for real GDP and unemployment, this study shows existence of a statistically significant and a strong negative relationship that existed between real GDP and the items of unemployment (such as total unemployment, male and female unemployment). It has also been found that the Swedish unemployment coefficients are higher than Okun's coefficient as measured by previous studies, possibly due to the special circumstance of the Swedish economic system. More specifically, the changes in employment were less responsive to economic growth in Sweden, this is the cause high unemployment benefits and other social security also offer supplemental income payments for unemployed people who have little track record in the labour force. Additionally, Swedish small and micro firms employed more than $53 \%$ of the total labour force, these firms move more quickly to bankruptcy than medium and large firms during the recession, therefore, these create greater unemployment. Moreover, possibly due to adopted heavy tax systems, new policies in the labour market, and more dependence on privatization, there is a move towards increased internationalization of all economic activity, advance in information technology and allowed increased competition between national and international markets (Note 3). 
This study found that the real GDP has a statistically significant and a negative effect on total unemployment, male unemployment and female unemployment, estimating it at $-0.076,-0.084$ and -0.079 respectively. In this regard, the analysis shows that economic growth is a considerable source of volatility for total unemployment, male unemployment and female unemployment variables in this model. Overall, the present results are thus roughly consistent with the findings reported in the literature. In addition, the findings of this study showed that the estimations of the relationship between the real GDP and unemployment coefficients are the same or very close for both males and females. It suggests that either Swedish policymakers used the same policies for both genders of Swedish employees (male and female) or without any differences or discrimination during the recession or that they have equal employment opportunities. The results of this study have important implications for determining macroeconomic policy.

\section{References}

Breusch, T. S. (1978). Testing for autocorrelation in dynamic linear models. Australian Economic Papers, 17, 334-355. http://dx.doi.org/10.1111/j.1467-8454.1978.tb00635.x

Brown, R. L., Durbin, J., \& Evans, J. M. (1975). Techniques for testing the constancy of regression relationships over time. Journal of the Royal Statistical Society, 37, 149-192.

Cuaresma, J. C. (2003). Okun's law revisited. Oxford Bulletin of Economic and Statistics, 65(4), 439-51. http://dx.doi.org/10.1111/1468-0084.t01-1-00056

Dickey, D. A., \& Fuller, W. A. (1979). Distribution of the estimators for autoregressive time series with a unit root. Journal of the American Statistical Association, 74, 427-431.

Dickey, D. A., \& Fuller, W. A. (1981). The likelihood ratio statistics for autoregressive time series with a unit root. Econometrica, 49(4), 1057-1072. http://dx.doi.org/10.2307/1912517

Döpke, J. (2001). The employment intensity' of growth in europe. Working paper, 1021. Kiel Institute of world economics. University of California, USA

Engle, R. F., \& Granger, C. W. A. (1987). Cointegration and error correction: representation, estimation and testing. Econometrica, 55, 251-581. http://dx.doi.org/10.2307/1913236

Godfrey, L. G. (1978). Testing for higher order serial correlation in regression equations when the regressors include lagged dependent variables. Econometrica, 46, 1303-1310. http://dx.doi.org/10.2307/1913830

Granger, C. W. J. (1969). Investigating causal relations by econometric models a cross-spectral method. Econometrica, 37, 24-36. http://dx.doi.org/10.2307/1912791

Holmlund, B. (2003). The rise and fall of Swedish unemployment. Working Paper series, 13. Department of Economics, Uppsala University, Sweden.

Jarque, C. M., \& Bera, A. K. (1987). A test for normality of observations and regression residuals. International Statistical Review, 55, 163-172. http://dx.doi.org/10.2307/1403192

Johansen, S. (1988). Statistical analysis of cointegration vectors. Journal of Economic Dynamics and Control, 12, 231-254. http://dx.doi.org/10.1016/0165-1889(88)90041-3

Lee, J. M. (2000). The robustness of Okun's law: evidence from OECD countries. Journal of Macroeconomics, 22(2), 331-356. http://dx.doi.org/10.1016/S0164-0704(00)00135-X

MacKinnon, J. G. (1991). Critical values for cointegration tests. In R. F. Engle \& C. W. A. Granger (Eds.), long-run economic relationships, readings in cointegration. Oxford University Press, London, Oxford.

Moosa, I. A. (1997). A cross-country comparison of Okun's coefficient. Journal of Comparative Economics, 24(3), 335-356. http://dx.doi.org/10.1006/jcec.1997.1433

Okun, A. M. (1962). Potential GNP: Its measurement and significance. Proceeding of the Business and Economics Statistics Section of the American Statistical Association, 89-104.

Padalino, S., \& Vivarelli, M. (1997). The employment of economic growth in the G-7 countries. International Labour Review, 136(2).

Piacentini, P., \& Pini, P. (1998). Growth, Productivity and employment: Do Income Distribution and internal Components of demand Matter? (2006-05-22) Retrieved from http://www.memo-europe.uni-bremen.de/doenloads/tnpini2.pdf

Pianta, M., Evangelista, R., \& Perani, G. (1996). The dynamics of innovation and employment: An International Comparison. Science Technology Industry Review, 18, 67-93. 
Prachowny, M. F. J. (1993). Okun's Law: Theoretical foundations and revised estimates. Review of Economics \& Statistics, 75(2), 331-335. http://dx.doi.org/10.2307/2109440

Ramsey, J. B. (1969). Test for specification error in classical linear least squares regression analysis. Journal of the Royal Statistical Society, 31, 350-371.

Salman, A. K., \& Shukur, G. (2004). Testing for granger causality between industrial output and CPI in the presence of regime shift: Swedish data. Journal of Economics Studies, 3(6), 492-499. http://dx.doi.org/10.1108/01443580410569235

Schwarz, G. (1978). Estimation the dimension of a model. Annals of Statistics, 6, 461-464. http://dx.doi.org/10.1214/aos/1176344136

Silvapulle, P., Moosa, I. A., \& Silvapulle, J. (2004). Asymmetry in Okuns's law. Canadian Journal of Economics, 37(2), 353-74. http://dx.doi.org/10.1111/j.0008-4085.2004.00006.x

Swedish Statistical Central Office (SCB). (2006 \& 2011). Statistical Year of Sweden. Labour force survey.

The organisation for economic co-operation and development (OECD). (2011). [database].

White, H. (1980). A Hetroskedasticity-Consistent Covariance Matrix Estimator and a Direct Test for Heteroskedastisity. Econometrica, 48, 817-838. http://dx.doi.org/10.2307/1912934

Zellner, A. (1962). An efficient method of estimating seemingly unrelated regression equations and tests for aggregation bias. Journal of the American Statistical Association, 57, 348-368. http://dx.doi.org/10.1080/01621459.1962.10480664

\section{Notes}

Note 1 . This study applied the Granger causality test to identify the relationship between the Swedish GDP with total unemployment, female unemployment and male unemployment for the period of study.

Note 2. Using different techniques, Lee (2000), Cuaresma (2003), Silvapulle \& others (2004). Investigated asymmetry in Okun's Law.

Note 3. Okun Coefficients vary because the relationship of unemployment to aggregate economic activity governed by laws technology and demographical and society changes. Lee (2000). Another factor that can contribute to variation in the coefficient of unemployment is the hours worked per worker. During economic downturns, the hours of work fall in response to decline in growth. Therefore, firms lay off workers and cut back on overtime.

\section{Appendix A}

Table A1. Results of ADF test for unit root to the GDP

\begin{tabular}{|c|c|c|c|}
\hline \multirow{2}{*}{\multicolumn{2}{|c|}{$\begin{array}{l}\text { Null Hypothesis: GDP has a unit root } \\
\text { Exogenous: None } \\
\text { Lag Length: } 0 \text { (Automatic based on SIC, MAXLAG=11) } \\
\end{array}$}} & \multirow[b]{2}{*}{ t-Statistic } & \multirow[b]{2}{*}{ Prob.* } \\
\hline & & & \\
\hline \multicolumn{2}{|c|}{ Augmented Dickey-Fuller test statistic } & -1.911170 & 0.0539 \\
\hline \multirow[t]{3}{*}{ Test critical values: } & 1\% level & -2.593121 & \\
\hline & $5 \%$ level & -1.944762 & \\
\hline & $10 \%$ level & -1.614204 & \\
\hline
\end{tabular}

Note: MacKinnon (1996) one-sided p-values.

Table A2. ADF test for Unit root total unemployment

Null Hypothesis: SWUNT has a unit root

Exogenous: Constant, Linear Trend

Lag Length: 2 (Automatic based on SIC, MAXLAG=11)

\begin{tabular}{lccc}
\hline & & t-Statistic & Prob.* $^{*}$ \\
\hline Augmented Dickey-Fuller test statistic & & -3.375121 & 0.0620 \\
\hline Test critical values: & $1 \%$ level & -4.075340 & \\
& $5 \%$ level & -3.466248 & \\
& $10 \%$ level & -3.159780 & \\
\hline
\end{tabular}

Note: MacKinnon (1996) one-sided p-values. 
Table A3. Results of ADF test for unit root GDP and male unemployment

Null Hypothesis: SWUNM has a unit root

Exogenous: Constant, Linear Trend

Lag Length: 1 (Automatic based on SIC, MAXLAG=11)

\begin{tabular}{lccc}
\hline & & t-Statistic & Prob.* $^{*}$ \\
\hline Augmented Dickey-Fuller test statistic & & -3.286306 & 0.0758 \\
\hline Test critical values: & 1\% level & -4.073859 & \\
& $5 \%$ level & -3.465548 & \\
& $10 \%$ level & -3.159372 & \\
\hline
\end{tabular}

Note: MacKinnon (1996) one-sided p-values.

Table A4. Results of ADF test for unit root GDP and female unemployment

Null Hypothesis: SWUNF has a unit root

Exogenous: Constant, Linear Trend

Lag Length: 2 (Automatic based on SIC, MAXLAG=11)

\begin{tabular}{lccc}
\hline & & t-Statistic & Prob.* \\
\hline Augmented Dickey-Fuller test statistic & & -3.004368 & 0.1375 \\
\hline Test critical values: & 1\% level & -4.075340 & \\
& $5 \%$ level & -3.466248 & \\
& $10 \%$ level & -3.159780 & \\
\hline
\end{tabular}

Note: MacKinnon (1996) one-sided p-values.

\section{Appendix B}

Table B1. The cointegration regression results for total unemployment

Sample(adjusted): 1993:1 2011:2

Included observations: 80 after adjusting endpoints

$\mathrm{t}$-statistics in parentheses

Dependent Variables

\begin{tabular}{|c|c|c|}
\hline Independent variables & GDP & TUn \\
\hline \multirow[t]{2}{*}{ GDP(t-1) } & 0.699678 & -0.076309 \\
\hline & (5.99413) & $(-4.43406)$ \\
\hline \multirow[t]{2}{*}{ GDP(t-2) } & 0.121202 & 0.038467 \\
\hline & $(0.81024)$ & $(1.74416)$ \\
\hline \multirow[t]{2}{*}{ GDP(t-3) } & -0.004125 & 0.018089 \\
\hline & $(-0.02711)$ & $(0.80631)$ \\
\hline \multirow[t]{2}{*}{ GDP(t-4) } & -0.282202 & -0.001516 \\
\hline & $(-2.34552)$ & $(-0.08546)$ \\
\hline \multirow[t]{2}{*}{ TUn(t-1) } & -0.339537 & 1.288171 \\
\hline & $(-0.41538)$ & (10.6889) \\
\hline \multirow[t]{2}{*}{ TUn(t-2) } & 0.179097 & -0.154083 \\
\hline & $(0.13418)$ & $(-0.78300)$ \\
\hline \multirow{2}{*}{ TUn(t-3) } & 0.112342 & -0.060805 \\
\hline & $(0.08457)$ & $(-0.31046)$ \\
\hline \multirow[t]{2}{*}{ TUn(t-4) } & 0.336124 & -0.115455 \\
\hline & $(0.41480)$ & $(-0.96638)$ \\
\hline \multirow[t]{2}{*}{ Intercept } & -0.874557 & 0.372134 \\
\hline & $(-0.98596)$ & $(2.84555)$ \\
\hline R-squared & 0.747097 & 0.980786 \\
\hline Adj. R-squared & 0.718601 & 0.978621 \\
\hline Sum sq. resids & 206.8354 & 4.496069 \\
\hline S.E. equation & 1.706802 & 0.251644 \\
\hline F-statistic & 26.21752 & 453.0223 \\
\hline Log likelihood & -151.5109 & 1.637844 \\
\hline Akaike AIC & 4.012773 & 0.184054 \\
\hline Schwarz SC & 4.280751 & 0.452032 \\
\hline Mean dependent & 2.263750 & 7.256250 \\
\hline S.D. dependent & 3.217525 & 1.721042 \\
\hline Determinant Residual Covariance & & 0.136907 \\
\hline Log Likelihood & & -147.4920 \\
\hline Akaike Information Criteria & & 4.137299 \\
\hline Schwarz Criteria & & 4.673255 \\
\hline
\end{tabular}


Table B2. The cointegration regression results for male unemployment

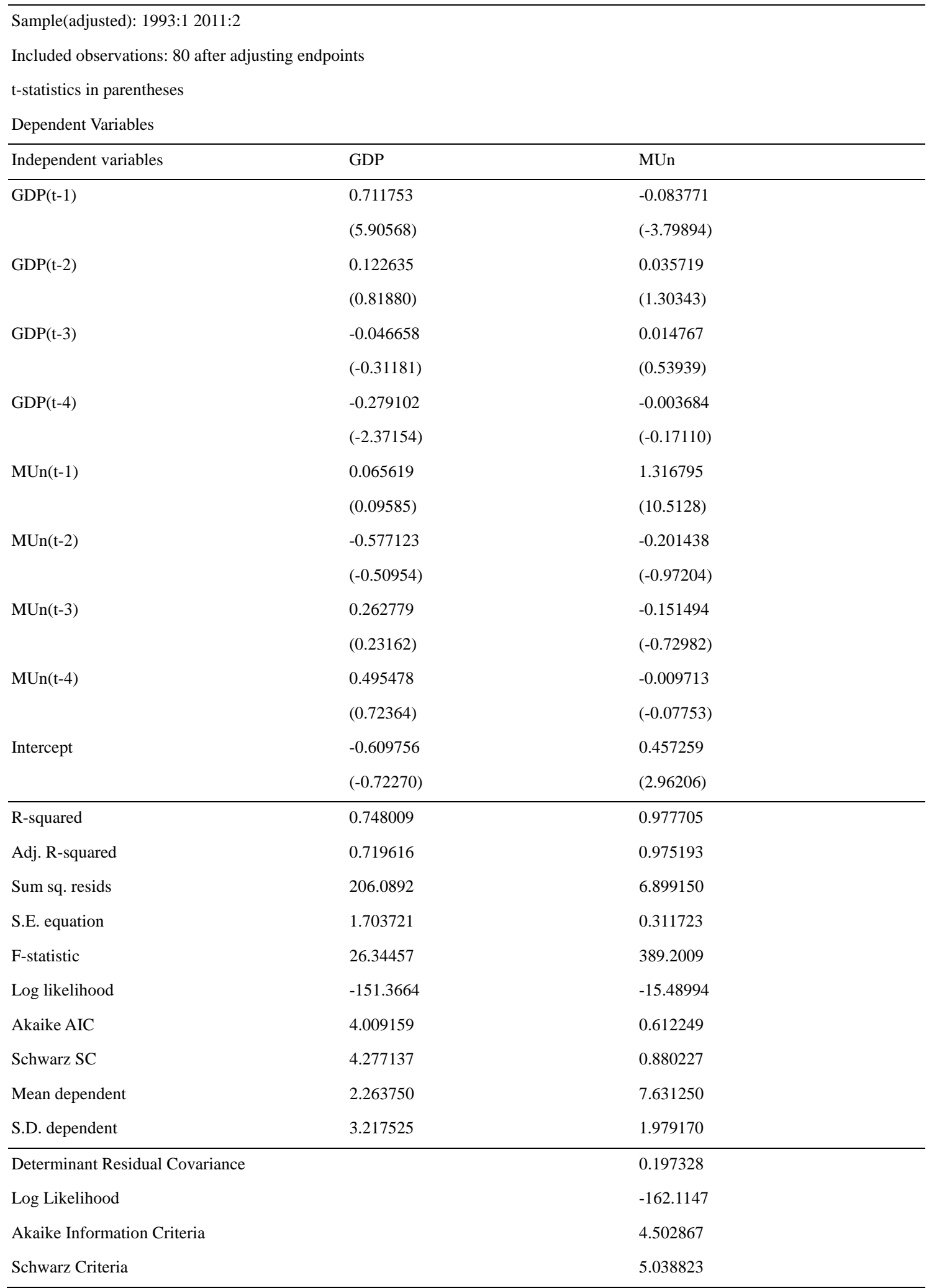


Table B3. The cointegration regression results for female unemployment

\begin{tabular}{|c|c|c|}
\hline \multicolumn{3}{|l|}{$\begin{array}{l}\text { Sample(adjusted): 1993:1 2011:2 } \\
\end{array}$} \\
\hline \multicolumn{3}{|c|}{ Included observations: 80 after adjusting endpoints } \\
\hline \multicolumn{3}{|l|}{ t-statistics in parentheses } \\
\hline \multicolumn{3}{|l|}{ Dependent Variables } \\
\hline Independent variables & GDP & FUn \\
\hline \multirow[t]{2}{*}{ GDP(t-1) } & 0.730644 & -0.079437 \\
\hline & $(6.46040)$ & $(-4.47779)$ \\
\hline \multirow[t]{2}{*}{ GDP(t-2) } & 0.118881 & 0.057498 \\
\hline & $(0.78019)$ & $(2.40563)$ \\
\hline \multirow[t]{2}{*}{ GDP(t-3) } & 0.011641 & 0.001624 \\
\hline & $(0.07372)$ & $(0.06558)$ \\
\hline \multirow[t]{2}{*}{ GDP(t-4) } & -0.251198 & -0.001560 \\
\hline & $(-2.07491)$ & $(-0.08217)$ \\
\hline \multirow[t]{2}{*}{ FUn(t-1) } & -0.546031 & 1.215346 \\
\hline & $(-0.73038)$ & (10.3638) \\
\hline \multirow[t]{2}{*}{ FUn(t-2) } & 0.389734 & -0.082276 \\
\hline & $(0.32990)$ & $(-0.44399)$ \\
\hline \multirow[t]{2}{*}{ FUn(t-3) } & 0.965979 & -0.046736 \\
\hline & $(0.83194)$ & $(-0.25660)$ \\
\hline \multirow[t]{2}{*}{ FUn(t-4) } & -0.517537 & -0.126604 \\
\hline & $(-0.71092)$ & $(-1.10869)$ \\
\hline \multirow[t]{2}{*}{ Intercept } & -1.003751 & 0.350044 \\
\hline & $(-1.17353)$ & $(2.60901)$ \\
\hline R-squared & 0.747745 & 0.974718 \\
\hline Adj. R-squared & 0.719322 & 0.971869 \\
\hline Sum sq. resids & 206.3053 & 5.076197 \\
\hline S.E. equation & 1.704614 & 0.267387 \\
\hline F-statistic & 26.30769 & 342.1591 \\
\hline Log likelihood & -151.4083 & -3.216508 \\
\hline Akaike AIC & 4.010207 & 0.305413 \\
\hline Schwarz SC & 4.278185 & 0.573391 \\
\hline Mean dependent & 2.263750 & 6.847500 \\
\hline S.D. dependent & 3.217525 & 1.594212 \\
\hline Determinant Residual Covariance & & 0.162992 \\
\hline Log Likelihood & & -154.4679 \\
\hline Akaike Information Criteria & & 4.311698 \\
\hline Schwarz Criteria & & 4.847654 \\
\hline
\end{tabular}




\section{Appendix C}

Table C1. Johansen's test for cointegration results of diagnostic tests GDP and total unemployment VAR(4) model. Series GDPSW SWUNT

Lags interval: 1 to 4

\begin{tabular}{lllll}
\hline & Likelihood & 5 Percent & 1 Percent & Hypothesized \\
\hline Eigenvalue & Ratio & Critical Value & Critical Value & No. of CE(s) \\
\hline 0.174352 & 27.80947 & 15.41 & 20.04 & None ** \\
0.148224 & 12.67413 & 3.76 & 6.65 & At most $1^{* *}$ \\
\hline
\end{tabular}

Note: Johansen's test for cointegration shows that these variables are cointegrated

Granger CAUSALITY TEST

Pairwise Granger Causality Tests

Date: 10/16/11 Time: 22:01

Sample: 1993:1 2011:2

\begin{tabular}{llll}
\hline Lags: 4 & & & \\
\hline Null Hypothesis: & Obs & F-Statistic & Probability \\
SWUNT does not Granger Cause GDPSW & 80 & 2.10061 & 0.08972 \\
GDPSW does not Granger Cause SWUNT & & 5.34247 & 0.00081 \\
\hline
\end{tabular}

Note: This means that GDP causes unemployment but not the other way around. Now we check the adequacy of these two equations; Single Equation regression of Unemployment on GDP

Dependent Variable: SWUNT ( Unemployment)

Method: Least Squares

Date: 10/16/11 Time: 22:48

Sample(adjusted): 1993:1 2011:2

Included observations: 80 after adjusting endpoints

\begin{tabular}{|c|c|c|c|c|}
\hline Variable & Coefficient & Std. Error & t-Statistic & Prob. \\
\hline $\mathrm{C}$ & 0.372134 & 0.130777 & 2.845553 & 0.0058 \\
\hline SWUNT(-1) & 1.288171 & 0.120515 & 10.68885 & 0.0000 \\
\hline SWUNT(-2) & -0.154083 & 0.196786 & -0.782998 & 0.4362 \\
\hline SWUNT(-3) & -0.060805 & 0.195850 & -0.310464 & 0.7571 \\
\hline SWUNT(-4) & -0.115455 & 0.119471 & -0.966382 & 0.3371 \\
\hline GDPSW(-1) & -0.076309 & 0.017210 & -4.434061 & 0.0000 \\
\hline GDPSW(-2) & 0.038467 & 0.022055 & 1.744158 & 0.0855 \\
\hline GDPSW(-3) & 0.018089 & 0.022435 & 0.806314 & 0.4228 \\
\hline GDPSW(-4) & -0.001516 & 0.017739 & -0.085459 & 0.9321 \\
\hline R-squared & 0.980786 & Mean dependent var & & 7.256250 \\
\hline Adjusted R-squared & 0.978621 & S.D. dependent var & & 1.721042 \\
\hline S.E. of regression & 0.251644 & Akaike info criterion & & 0.184054 \\
\hline Sum squared resid & 4.496069 & Schwarz criterion & & 0.452032 \\
\hline Log likelihood & 1.637844 & F-statistic & & 453.0223 \\
\hline Durbin-Watson stat & 2.017627 & Prob(F-statistic) & & 0.000000 \\
\hline \multicolumn{5}{|c|}{ Breusch-Godfrey Serial Correlation LM Test: 4 lags } \\
\hline F-statistic & 1.595776 & Probability & 0.185631 & \\
\hline Obs*R-squared & 6.958665 & Probability & 0.138089 & \\
\hline \multicolumn{5}{|c|}{ The results indicate no autocorrelation. } \\
\hline \multicolumn{5}{|c|}{ White Heteroskedasticity Test: } \\
\hline F-statistic & 0.766385 & Probability & 0.715747 & \\
\hline Obs*R-squared & 13.03407 & Probability & 0.670265 & \\
\hline \multicolumn{5}{|l|}{ ARCH Test: } \\
\hline F-statistic & 2.784343 & Probability & 0.099251 & \\
\hline Obs*R-squared & 2.756970 & Probability & 0.096831 & \\
\hline \multicolumn{5}{|c|}{ RESET test for misspecification } \\
\hline \multicolumn{5}{|l|}{ Ramsey RESET Test: } \\
\hline F-statistic & 1.710377 & Probability & 0.157988 & \\
\hline Log likelihood ratio & 7.778271 & Probability & 0.100047 & \\
\hline
\end{tabular}


Tests for parameter stability that show stable parameters

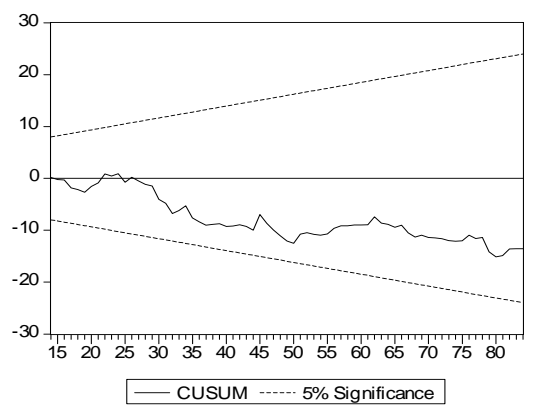

Figure 1.

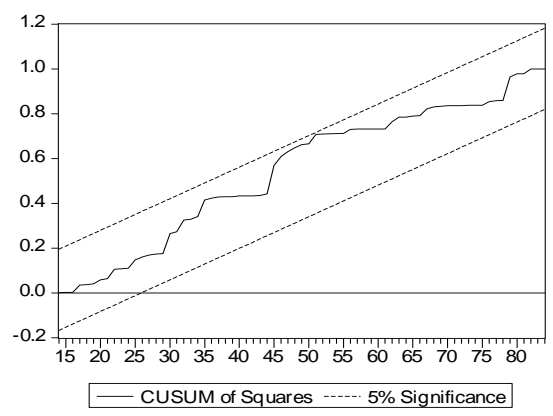

Figure 2.

\section{Single Equation regression of GDP on Unemployment}

Dependent Variable: GDPSW ( Swedish GDP)

Method: Least Squares

Date: 10/16/11 Time: 22:52

Sample(adjusted): 1993:1 2011:2

Included observations: 80 after adjusting endpoints

\begin{tabular}{|c|c|c|c|c|}
\hline Variable & Coefficient & Std. Error & t-Statistic & Prob. \\
\hline $\mathrm{C}$ & -0.874557 & 0.887010 & -0.985961 & 0.3275 \\
\hline SWUNT(-1) & -0.339537 & 0.817407 & -0.415384 & 0.6791 \\
\hline SWUNT(-2) & 0.179097 & 1.334723 & 0.134183 & 0.8936 \\
\hline SWUNT(-3) & 0.112342 & 1.328375 & 0.084571 & 0.9328 \\
\hline SWUNT(-4) & 0.336124 & 0.810325 & 0.414802 & 0.6795 \\
\hline GDPSW(-1) & 0.699678 & 0.116727 & 5.994130 & 0.0000 \\
\hline GDPSW(-2) & 0.121202 & 0.149589 & 0.810235 & 0.4205 \\
\hline GDPSW(-3) & -0.004125 & 0.152166 & -0.027112 & 0.9784 \\
\hline GDPSW(-4) & -0.282202 & 0.120315 & -2.345524 & 0.0218 \\
\hline R-squared & 0.747097 & Mean dependent var & & 2.263750 \\
\hline Adjusted R-squared & 0.718601 & S.D. dependent var & & 3.217525 \\
\hline S.E. of regression & 1.706802 & Akaike info criterion & & 4.012773 \\
\hline Sum squared resid & 206.8354 & Schwarz criterion & & 4.280751 \\
\hline Log likelihood & -151.5109 & F-statistic & & 26.21752 \\
\hline Durbin-Watson stat & 1.911781 & Prob(F-statistic) & & 0.000000 \\
\hline \multicolumn{5}{|c|}{ Breusch-Godfrey Serial Correlation LM Test: } \\
\hline F-statistic & 1.073418 & Probability & 0.376662 & \\
\hline Obs*R-squared & 4.818010 & Probability & 0.306486 & \\
\hline \multicolumn{5}{|c|}{ White Heteroskedasticity Test: } \\
\hline F-statistic & 1.186083 & Probability & 0.303717 & \\
\hline Obs*R-squared & 18.51958 & Probability & 0.294361 & \\
\hline \multicolumn{5}{|l|}{ ARCH Test: } \\
\hline F-statistic & 6.114025 & Probability & 0.015616 & \\
\hline Obs*R-squared & 5.811390 & Probability & 0.015923 & \\
\hline \multicolumn{5}{|l|}{ Ramsey RESET Test: } \\
\hline F-statistic & 1.071543 & Probability & 0.377577 & \\
\hline Log likelihood ratio & 4.960779 & Probability & 0.291345 & \\
\hline
\end{tabular}

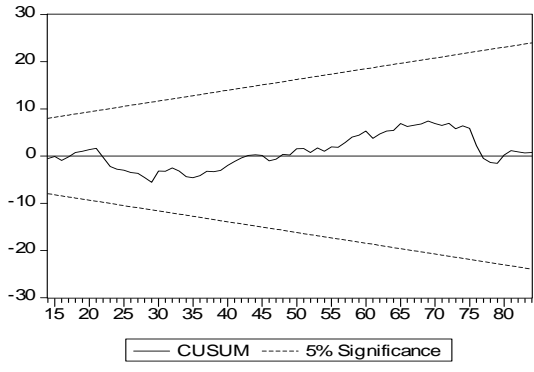

Figure 3.

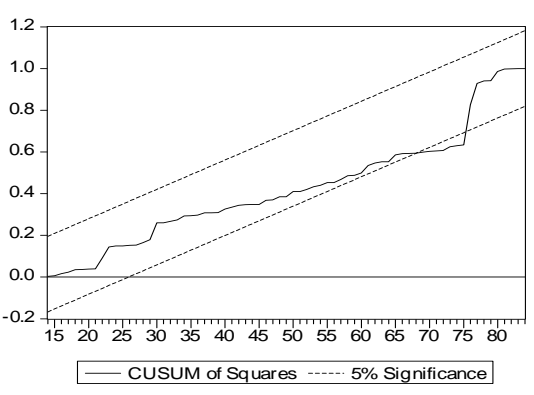

Figure 4. 
Table C2. Johansen's test for cointegration results of diagnostic tests GDP and male unemployment VAR(4) model. Series GDPSW SWUNM

Lags interval: 1 to 4

\begin{tabular}{lllll}
\hline Eigenvalue & Likelihood & 5 Percent & 1 Percent & Hypothesized \\
Ratio & Critical Value & Critical Value & No. of CE(s) \\
\hline 0.190247 & 29.02685 & 15.41 & 20.04 & None ** \\
0.144785 & 12.35583 & 3.76 & 6.65 & At most $1^{* *}$ \\
\hline
\end{tabular}

Note: Johansen's test for cointegration shows that these variables are cointegrated

Pairwise Granger Causality Tests

Date: 10/16/11 Time: 22:21

Sample: 1993:1 2011:2

Lags: 4

Null Hypothesis:

SWUNM does not Granger Cause GDPSW

Obs
F-Statistic

2.17248 Probability

GDPSW does not Granger Cause SWUNM

3.84429

0.08081

Single Equation regression of Unemployment on GDP

Dependent Variable: SWUNM

Method: Least Squares

Date: 10/16/11 Time: 22:55

Sample(adjusted): 1993:1 2011:2

Included observations: 80 after adjusting endpoints

\begin{tabular}{|c|c|c|c|c|}
\hline Variable & Coefficient & Std. Error & t-Statistic & Prob. \\
\hline C & 0.457259 & 0.154372 & 2.962062 & 0.0042 \\
\hline 2. SWUNM(-1) & 1.316795 & 0.125257 & 10.51278 & 0.0000 \\
\hline SWUNM(-2) & -0.201438 & 0.207232 & -0.972042 & 0.3343 \\
\hline SWUNM(-3) & -0.151494 & 0.207576 & -0.729824 & 0.4679 \\
\hline SWUNM(-4) & -0.009713 & 0.125277 & -0.077534 & 0.9384 \\
\hline 1.GDPSW(-1) & -0.083771 & 0.022051 & -3.798936 & 0.0003 \\
\hline GDPSW(-2) & 0.035719 & 0.027404 & 1.303435 & 0.1966 \\
\hline GDPSW(-3) & 0.014767 & 0.027378 & 0.539387 & 0.5913 \\
\hline GDPSW(-4) & -0.003684 & 0.021533 & -0.171097 & 0.8646 \\
\hline R-squared & 0.977705 & Mean dependent var & & 7.631250 \\
\hline Adjusted R-squared & 0.975193 & S.D. dependent var & & 1.979170 \\
\hline S.E. of regression & 0.311723 & Akaike info criterion & & 0.612249 \\
\hline Sum squared resid & 6.899150 & Schwarz criterion & & 0.880227 \\
\hline Log likelihood & -15.48994 & F-statistic & & 389.2009 \\
\hline Durbin-Watson stat & 2.008343 & Prob(F-statistic) & & 0.000000 \\
\hline \multicolumn{5}{|c|}{ Breusch-Godfrey Serial Correlation LM Test: } \\
\hline F-statistic & 2.483113 & Probability & 0.051899 & \\
\hline Obs*R-squared & 10.32849 & Probability & 0.035243 & \\
\hline \multicolumn{5}{|c|}{ White Heteroskedasticity Test: } \\
\hline F-statistic & 0.808586 & Probability & 0.670873 & \\
\hline Obs*R-squared & 13.62952 & Probability & 0.626292 & \\
\hline \multicolumn{5}{|l|}{ ARCH Test: } \\
\hline F-statistic & 1.823159 & Probability & 0.180893 & \\
\hline Obs*R-squared & 1.827249 & Probability & 0.176453 & \\
\hline \multicolumn{5}{|l|}{ Ramsey RESET Test: } \\
\hline F-statistic & 1.150586 & Probability & 0.340567 & \\
\hline Log likelihood ratio & 5.314817 & Probability & 0.256493 & \\
\hline
\end{tabular}

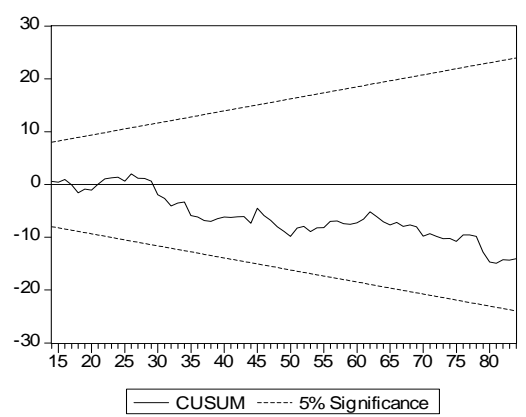

Figure 5.

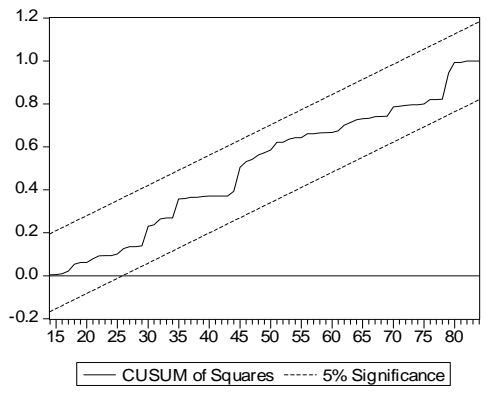

Figure 6. 


\section{Single Equation regression of GDP on Unemployment}

Dependent Variable: GDPSW

Method: Least Squares

Date: 10/16/11 Time: 22:58

Sample(adjusted): 1993:1 2011:2

Included observations: 80 after adjusting endpoints

\begin{tabular}{lllll}
\hline Variable & Coefficient & Std. Error & t-Statistic & Prob. \\
\hline C & -0.609756 & 0.843719 & -0.722700 & 0.4722 \\
SWUNM(-1) & 0.065619 & 0.684590 & 0.095851 & 0.9239 \\
SWUNM(-2) & -0.577123 & 1.132626 & -0.509545 & 0.6120 \\
SWUNM(-3) & 0.262779 & 1.134507 & 0.231624 & 0.8175 \\
SWUNM(-4) & 0.495478 & 0.684702 & 0.723640 & 0.4717 \\
GDPSW(-1) & 0.711753 & 0.120520 & 5.905682 & 0.0000 \\
GDPSW(-2) & 0.122635 & 0.149774 & 0.818798 & 0.4156 \\
GDPSW(-3) & -0.046658 & 0.149635 & -0.311810 & 0.7561 \\
GDPSW(-4) & -0.279102 & 0.117688 & -2.371538 & 0.0204 \\
\hline R-squared & 0.748009 & Mean dependent var & 2.263750 \\
Adjusted R-squared & 0.719616 & S.D. dependent var & & 3.217525 \\
S.E. of regression & 1.703721 & Akaike info criterion & & 4.009159 \\
Sum squared resid & Schwarz criterion & & 4.277137 \\
Log likelihood & 206.0892 & F-statistic & & 26.34457 \\
Durbin-Watson stat & -151.3664 & Prob(F-statistic) & & 0.000000 \\
\hline Breusch-Godfrey Serial Correlation LM Test: & & \\
\hline F-statistic & 1.900164 & Probability & 0.128574 & \\
Obs*R-squared & 2.365223 & Probability & 0.105873 \\
\hline Breusch-Godfrey Serial Correlation LM Test: & & \\
\hline F-statistic & 2.614762 & Probability & 0.418310 & \\
Obs*R-squared & 0.991559 & Probability & 0.345985 & \\
\hline
\end{tabular}

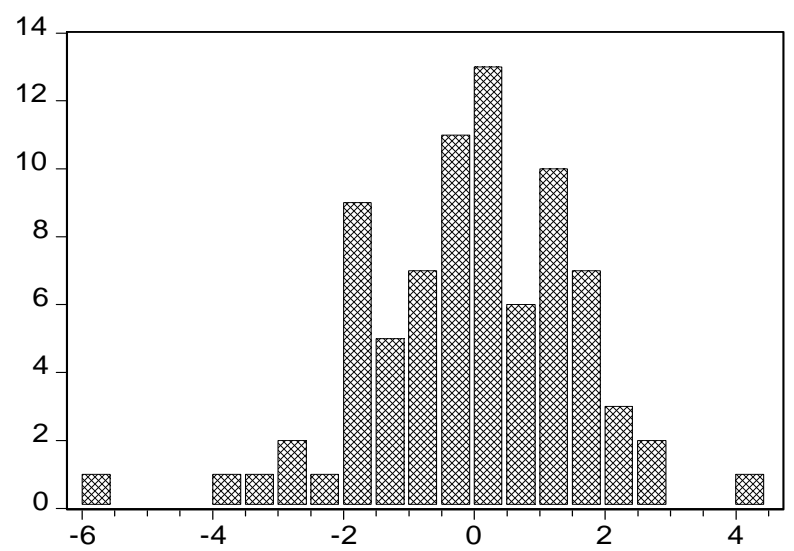

\begin{tabular}{|lr|}
\hline \multicolumn{2}{|l|}{ Series: Residuals } \\
Sample 1905 1984 \\
Observations 80 \\
\\
Mean & -1.10 E-16 \\
Median & 0.057919 \\
Maximum & 4.463097 \\
Minimum & -5.818656 \\
Std.Dev. & 1.615155 \\
Skewness & -0.452623 \\
Kurtosis & 4.341101 \\
& \\
Jarque-Bera & 8.726744 \\
Probability & 0.012735 \\
\hline
\end{tabular}

Figure 7.

White Heteroskedasticity Test:

\begin{tabular}{llll}
\hline F-statistic & 0.977010 & Probability & 0.491726 \\
Obs*R-squared & 15.90409 & Probability & 0.459675 \\
\hline ARCH Test: & & & \\
\hline F-statistic & 4.767382 & Probability & 0.032050 \\
Obs*R-squared & 4.606032 & Probability & 0.031860 \\
\hline Ramsey RESET Test: & & & \\
\hline F-statistic & 1.220334 & Probability & 0.310504 \\
Log likelihood ratio & 5.625921 & Probability & 0.228881 \\
\hline
\end{tabular}




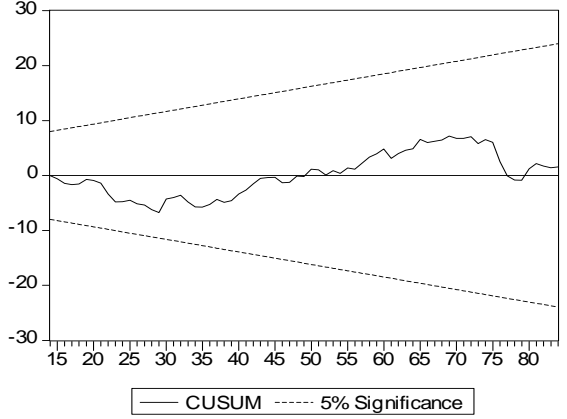

Figure 8.

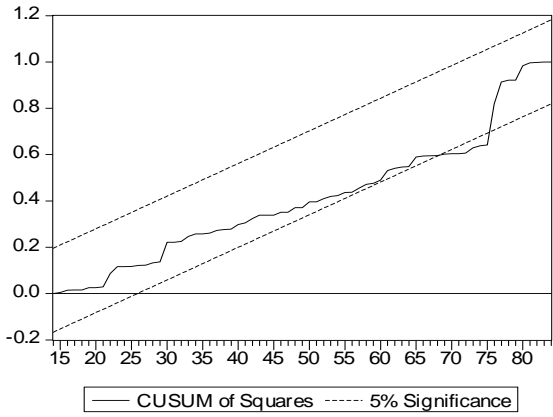

Figure 9.

Table C3. Johansen's test for cointegration results of diagnostic tests GDP and female unemployment VAR(4) model

Cointegration tests. Series GDPSW SWUNF

Lags interval: 1 to 4

\begin{tabular}{lllll}
\hline & Likelihood & 5 Percent & 1 Percent & Hypothesized \\
Eigenvalue & Ratio & Critical Value & Critical Value & No. of CE(s) \\
\hline 0.174233 & 24.56101 & 15.41 & 20.04 & None ** \\
0.112597 & 9.437009 & 3.76 & 6.65 & At most 1 ** \\
\hline
\end{tabular}

Note: Johansen's test for cointegration shows that these variables are cointegrated.

Pairwise Granger Causality Tests

Date: 10/16/11 Time: 22:40

Sample: 1993:1 2011:2

Lags: 4

\begin{tabular}{llll}
\hline Null Hypothesis: & Obs & F-Statistic & Probability \\
\hline SWUNF does not Granger Cause GDPSW & 80 & 2.15162 & 0.08330 \\
GDPSW does not Granger Cause SWUNF & & 5.28517 & 0.00088 \\
\hline
\end{tabular}

Single Equation regression of Unemployment on GDP

Dependent Variable: SWUNF

Method: Least Squares

Date: 10/16/11 Time: 22:42

Sample(adjusted): 1993:1 2011:2

Included observations: 80 after adjusting endpoints

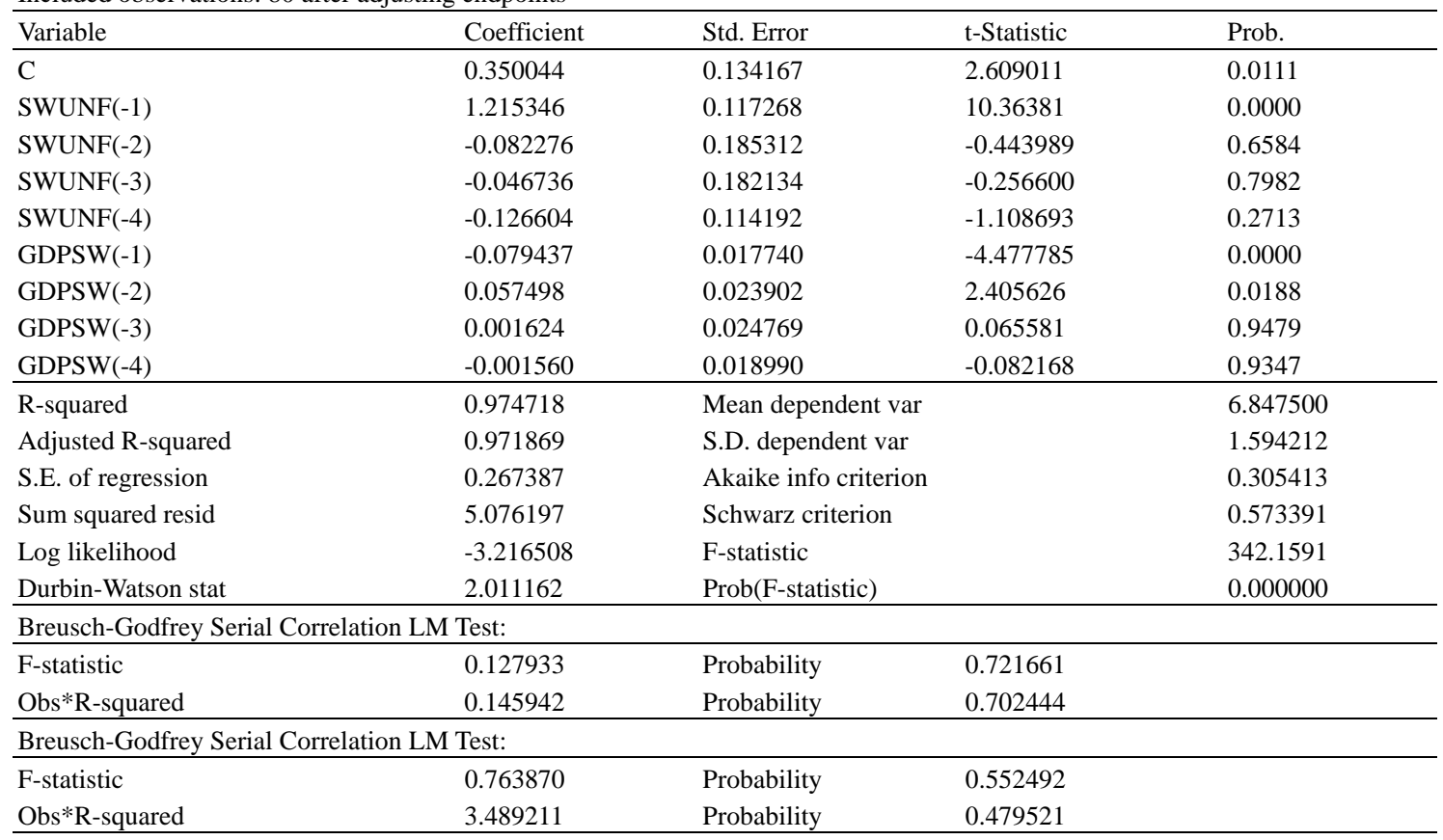


White Heteroskedasticity Test:

\begin{tabular}{llll}
\hline F-statistic & 0.913998 & Probability & 0.557433 \\
Obs*R-squared & 15.07160 & Probability & 0.519401 \\
\hline ARCH Test: & & & \\
\hline F-statistic & 0.126084 & Probability & 0.723498 \\
Obs*R-squared & 0.129148 & Probability & 0.719317 \\
\hline Ramsey RESET Test: & & & \\
\hline F-statistic & 0.437374 & Probability & 0.781146 \\
Log likelihood ratio & 2.062145 & Probability & 0.724330 \\
\hline
\end{tabular}

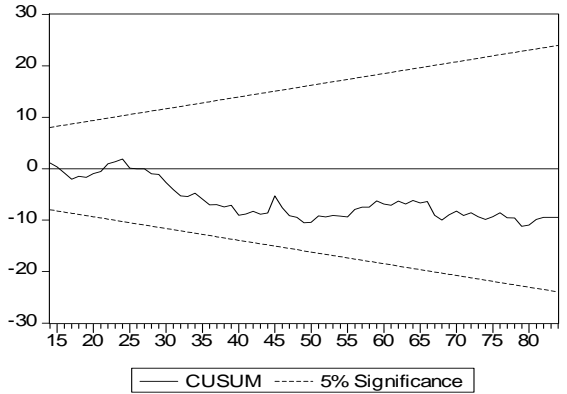

Figure 10.

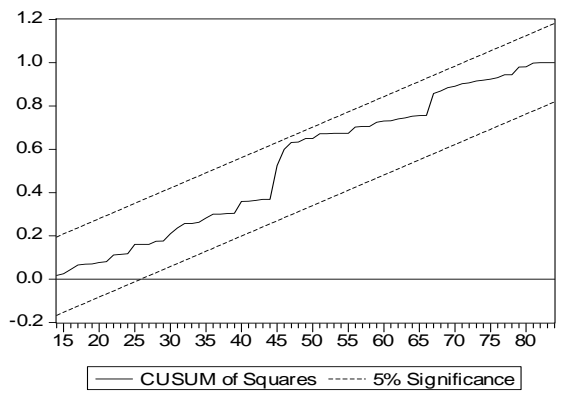

Figure 11.

\section{Single Equation regression of GDP on Unemployment}

Dependent Variable: GDPSW

Method: Least Squares

Date: 10/16/11 Time: 22:45

Sample(adjusted): 1993:1 2011:2

Included observations: 80 after adjusting endpoints

\begin{tabular}{|c|c|c|c|c|}
\hline Variable & Coefficient & Std. Error & t-Statistic & Prob. \\
\hline $\mathrm{C}$ & -1.003751 & 0.855327 & -1.173529 & 0.2445 \\
\hline SWUNF(-1) & -0.546031 & 0.747596 & -0.730383 & 0.4676 \\
\hline SWUNF(-2) & 0.389734 & 1.181378 & 0.329898 & 0.7424 \\
\hline SWUNF(-3) & 0.965979 & 1.161119 & 0.831938 & 0.4082 \\
\hline SWUNF(-4) & -0.517537 & 0.727982 & -0.710920 & 0.4795 \\
\hline GDPSW(-1) & 0.730644 & 0.113096 & 6.460399 & 0.0000 \\
\hline GDPSW(-2) & 0.118881 & 0.152375 & 0.780192 & 0.4379 \\
\hline GDPSW(-3) & 0.011641 & 0.157906 & 0.073720 & 0.9414 \\
\hline GDPSW(-4) & -0.251198 & 0.121064 & -2.074912 & 0.0416 \\
\hline R-squared & 0.747745 & Mean dependent var & & 2.263750 \\
\hline Adjusted R-squared & 0.719322 & S.D. dependent var & & 3.217525 \\
\hline S.E. of regression & 1.704614 & Akaike info criterion & & 4.010207 \\
\hline Sum squared resid & 206.3053 & Schwarz criterion & & 4.278185 \\
\hline Log likelihood & -151.4083 & F-statistic & & 26.30769 \\
\hline Durbin-Watson stat & 1.907445 & Prob(F-statistic) & & 0.000000 \\
\hline \multicolumn{5}{|c|}{ Breusch-Godfrey Serial Correlation LM Test: } \\
\hline F-statistic & 1.625030 & Probability & 0.206607 & \\
\hline Obs*R-squared & 1.815042 & Probability & 0.177905 & \\
\hline \multicolumn{5}{|c|}{ Breusch-Godfrey Serial Correlation LM Test: } \\
\hline F-statistic & 1.183255 & Probability & 0.326190 & \\
\hline Obs*R-squared & 5.278484 & Probability & 0.259898 & \\
\hline \multicolumn{5}{|c|}{ White Heteroskedasticity Test: } \\
\hline F-statistic & 1.415529 & Probability & & 0.163750 \\
\hline Obs*R-squared & 21.15481 & Probability & & 0.172636 \\
\hline \multicolumn{5}{|l|}{ ARCH Test: } \\
\hline F-statistic & 6.527494 & Probability & 0.012594 & \\
\hline Obs*R-squared & 6.173680 & Probability & 0.012966 & \\
\hline \multicolumn{5}{|l|}{ Ramsey RESET Test: } \\
\hline F-statistic & 0.919027 & Probability & 0.458154 & \\
\hline Log likelihood ratio & 4.273196 & Probability & 0.370294 & \\
\hline
\end{tabular}




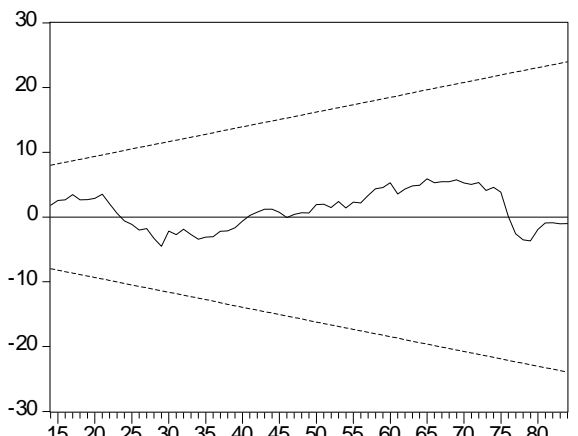

$\begin{array}{lllllllllllllll}15 & 20 & 25 & 30 & 35 & 40 & 45 & 50 & 55 & 60 & 65 & 70 & 75 & 80\end{array}$

- CUSUM --.-. 5\% Significance

Figure 12.

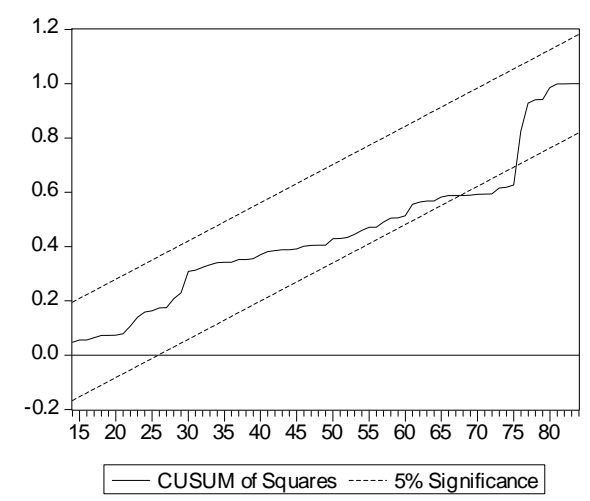

Figure 13. 